\title{
Okuma Eğitimi Alanındaki Kuramsal Kitaplarda Okumanın Kavram Alanına Yönelik Eleștirel Bir Değerlendirme*
}

\author{
A Critical Evaluation of the Field Concept of Reading in \\ Theoretical Books in the Discipline of Reading Education
}

\author{
Faik KANATLI**, Yunus Emre ÇEKİCI***
}

\begin{abstract}
Öz: Türkçe öğretmenliği lisans programlarının 5. döneminde "Anlama Teknikleri 1: Okuma Eğitimi” adlı ders verilir. Bu derste genellikle Türkçe öğretimi ile ilgili kaynakların okuma eğitimi bölümleri ve/veya başılı başına okuma eğitimini konu alan ders kitapları okutulur. Okuma eğitimi ile ilgili ders kitaplarının ve bölümlerin okumanın kavram alanını yansıtması, okumayı ve okutmayı özendirmesi ve öğretmen adaylarını okuma eğitimine hazırlaması beklenir. Bu çalışmanın amacı, Türkçe öğretmeni yetiştirirken okuma eğitimi alanında sıklıkla kullanılan on ders kitabında ön plana çıkan okumanın kavram alanını tartışmaya açmaktır. İncelenen on ders kitabı belirlenirken temsil yeterliliği için uzman görüşüne başvurulmuştur. Örneklem alınan kitaplarda ön plana çıkan kavramlar sınıflandırılmış ve örneklendirilmiştir. Ayrıca Almanca ve edebiyat dersinin gelişim tarihinin ele alındığı iki kaynak da yine okumanın kavram alanını belirlemek amacıyla değerlendirilmiş, böylece Türkçe ve Almanca eğitiminde okumanın kavram alanına ilişkin farklılıklar üzerinde durulmuştur. Betimsel bir nitelik taşıyan bu çalışmada içerik analizi yöntemi kullanılmıştır. Türkçe kitaplarda tespit edilen kavramlar şunlardır: fizyolojik kavramlar, fiziksel kavramlar, alışkanlık, hız, metin, bilgi, kelime hazinesi, sosyallik ve anlama. Almanca kaynaklarda Türkçe kaynaklardan farklı olan bazı kavramlar ise şunlardır: okuma sosyalleşmesi, yazınsal sosyalleşme, alımlama estetiği, metin ve okur etkileşimi, özerklik, birey olma, kimlik/kişilik geliştirici/güçlendirici bir süreç olarak okuma, özeleştirel okuma, okuma dinamiği, okuma heyecanı, okuma coşkusu, okuma iklimi, okuma motivasyonu, okuma deneyimi, okuma yapılandırması. Bu çalışmada, ortaya çıkan bu farklılıkların nedenleri değerlendirilmiştir.

Anahtar Kelimeler: Türkçe öğretmeni yetiştirme, okuma, okuma eğitimi, kavram alanı, eleştirel okuma
\end{abstract}

\begin{abstract}
The course titled "Understanding Techniques 1: Reading Education" is given in the 5th semester of Turkish language teaching programs. In this course, reading education sections of Turkish education sources are examined or, in these lessons, textbooks titled "reading education" are read. These books and chapters should reflect the field concept of reading and encourage reading. These books should prepare teacher candidates for reading instruction. The aim of this study is to determine the field concept of reading in theoretical books in the field of reading education. For this purpose, ten theoretical books were examined. When these books were determined, expert opinion was applied for the adequacy of representation. The concepts in the sampled books were classified and explained in the "findings" section. In addition, two sources addressing the development history of the German language and literature course were evaluated in order to determine the field concept of reading. Thus, differences in the field concept of reading in Turkish education and German language education are emphasized. This study is descriptive. Content analysis method was used in this study. Concepts found in Turkish books are: physiological concepts, physical concepts, habit, speed, text, knowledge, vocabulary, sociability and comprehension. Some concepts that are different from Turkish sources in German sources are: reading socialization, literary socialization, reception aesthetics, text and reader interaction, autonomy, individuality, reading as an identity / personality enhancing process, self-critical reading, reading dynamics, reading climax, reading climate, reading motivation, reading experience, reading structuring. The reasons for these differences have been evaluated in this study.

Keywords: Turkish teacher training, reading, reading education, field concept, critical reading
\end{abstract}

\footnotetext{
"Bu çalışma, 20-23 Nisan 2017'de Roma'da düzenlenen 3. Uluslararası Dil Eğitimi ve Öğretimi Sempozyumunda sözlü bildiri olarak sunulmuştur.

***Prof. Dr., Mersin Üniversitesi, Eğitim Fakültesi, Türkiye-Mersin, e-posta: fkanatli@ mersin.edu.tr

**** Okutman, Adana Bilim ve Teknoloji Üniversitesi, TÖMER, Türkiye-Adana, e-posta:yunusemrecekici@ gmail.com
} 


\section{Giriş}

Her ne kadar medyanın ve farklı iletişim seçeneklerinin insan yaşamındaki etkisi giderek yoğunlaşsa da okuma eylemi, hâlâ düşünmeyi deneyimlemenin ve anlamanın odağını oluşturur. Düşünmeyi deneyimleme ve anlamlandırmadaki belirgin etkisi nedeniyle okuma, her dönemde eğitim tartışmalarının odağında yer almıştır. Bu yüzden günümüzde de eğitim alanındaki başarının temel belirleyicisi, okuma olarak kabul edilir. Bugün, üç farklı beceriyi ölçen PISA'nın zemininde de okuma yer alır. 2015 yılındaki PISA sonuçlarına göre, okuma becerisi alanında Türkiye'nin 72 ülke içinde 50. olması (MEB, 2016: 24), şu temel sorunu gündeme getirir: Türkiye'de az kitap okuma sorunu olduğu kadar, okuyanların da okuduğunu anlama sorunu vardır. O hâlde dünyanın her yerinde olduğu gibi, okuma eğitimini sürekli yeniden değerlendirmek gerekliliği ortaya çıkar. Bu bağlamda, okuma eğitiminin kavram alanını tartışmak hem yararlı hem de zorunlu hâle gelmektedir.

Farklı ülkelerde farklı yaklaşımlarla ele alınsa da okuma edimi ve eğitimi; tüm eğitim dizgeleri, dil ve kültürlerde ana dili ve edebiyat dersleriyle özdeşleştirilmiştir. Ülkemizde de ilkokul ve ortaokul düzeyinde okuma becerisinin Türkçe derslerinde kazandırılması ve geliştirilmesi temel bir amaç olarak belirginleşir. Türkçe derslerinde kazandırılması beklenen dört ana dil becerisinden biri okuma olduğu için, Türkçe öğretmeni yetiştiren lisans programının temelinde de okuma eğitimi yer alır. Türkiye'de, Eğitim Fakültelerinin Türkçe Eğitimi lisans programlarının 5. döneminde, dört saatlik "Anlama Teknikleri 1: Okuma Eğitimi”" adlı ders verilir. Bu derslerde genellikle Türkçe öğretimiyle ilgili kuramsal kaynakların okuma eğitimi bölümlerinden ve/veya başlı başına okuma eğitimini konu alan kuramsal kitaplardan yararlanılır. Okuma eğitimiyle ilgili kuramsal kitap ve bölümlerden; okumanın kavram alanını yansıtması, öğretmen adaylarını okuma eğitimine hazırlaması, onları okumaya ve okutmaya özendirmesi beklenir. İletişimsel, sosyal, yazınsal, bilişsel, fizyolojik arka alanı olan okuma gibi çok bileşenli bir kavramı sorunsallaştıran kuramsal kitapların, okumanın bu çok yönlü kavram alanını yansıtması bir gerekliliktir.

Kavram alanı, okuma eğitimi alanındaki düşünsel ve akademik birikimi yansıtır. Okuma eğitimine ilişkin kuramsal kitapların öncelediği veya göz ardı ettiği kavramlar, bir anlamda okumanın düşünce dünyamızdaki kavram alanını da belirginleştirebilir. Tümüyle özgür ve keyfi bir edim, sonu belirsiz bir bulgulama eylemi olarak nitelenen (Kula, 2008, s. 21); farklı olana doğru kürek çekmek; farklı olanla tanışmak, dost olmak ve ziyaretleşmek olarak da tanımlanan okuma (Kanatlı ve Çekici, 2011, s. 278); acaba ilgili kuramsal kitaplarda, hangi kavramlarla beraber yapılandırılmaktadır? Başka bir anlatımla metinde yeni bir tat bulmak, o metnin ilginç bir yanını yakalamak (Eziler Kıran ve Kıran, 2011, s. 359) ve metindeki anlamı yeniden üretmek yani metni yeniden yaratmak olan okumayı (Eziler Kıran ve Kıran, 2011, s. 17) konulaştıran kuramsal kitaplarda, hangi kavramlar ön plana çıkmaktadır? Bu bağlamda, söz konusu araştırma sorularına yanıt aramadan önce, anlambilimsel bir kuram ve inceleme yöntemi olan, bu çalışmanın da zemininde yer alan "kavram alanı"nı açıklamak, bir gereklilik olarak ortaya çıkmaktadır.

\section{Kavram alanı}

Anlambilim araştırmalarında önemli bir yer tutan "kavram alanı" kuramında, bir terim birliğinden söz etmek güçtür. J. Trier, A. Jolles, K. Bühler, W. Portzig, L. Weisberger, B. Ipsen gibi adlarla anılan kavram alanı terimiyle; dilsel alan, dil alanı, sözlüksel alan, sözdizimsel alan, anlamsal alan, anlam alanı, anlam yerleşkesi, anlamsal ă̆, anlamsal örgü, çağrışımsal alan ve alan kuramı terimleri; kimi ince ayrımlar gösterse de eş anlamlı olarak değerlendirilebilir (Bkz. Lewandowsky, 1990, s. 154, s. 299-302, s. 1261-1262). Dilsel tutarlılı̆̆1 sağlamak adına bu çalışmada "kavram alanı" terimi tercih edilmiştir.

Özellikle Alman dilbilimci J. Trier'in dil alanı (sprachfeld) adıyla uyguladığı, sonradan başkalarınca da ele alınan kuram; kavramların da tıpkı mozaik gibi birbirini sınırlandıran ve gerektiren çeşitli parçacıkların birleşmesinden oluşmuş bir alan içinde bulundukları ilkesinden yola çıkarak her kavramın değerinin ancak kapladığı yerle ve öteki kavramlarla ilişkisine göre belli olacağını ifade eder (Aksan, 1971, s. 254). Kavram alanı kuramının temeli; kavramların 
birbirinden soyutlanmış olarak ayrı ayrı değil, bir mozaik gibi birbirlerini sınırlandırdıkları, etkiledikleri görüşüne dayanır (Aksan, 2016, s. 54). Kavram alanı, anlamca akraba veya komşu sözcüklerden oluşur ve aynı kavram alanındaki sözcüklerin sınır çizgileri birbiriyle kesişir (Toklu, 2003, s. 100). Portzig (1995, s. 86), bir kelimenin anlamını belirlemeye çalıştı̆̆ımızda, aynı kavram alanındaki birbirine sıkı sıkıya bağlı diğer sözcüklere gereksinim duyduğumuzu belirtir. Hatta Portzig'e göre (1995, s. 92), konuşucu birbirine sık1 sıkıya bağlı sözcüklere muhtaçtır, hiçbir zaman tam anlamıyla özgür değildir. Çünkü kavram alanı, konuşucunun düşünmesini de sınırlar. Bu görüşlerden yola çıkarak bir tanım önerilebilir: İç içe geçmiş, kaynaşmış, bir sözcüğün diğerini etkilediği-gerektirdiği, sözcüklerin anlam sınırlarının kesiştiği ve anlamlarının birbiriyle belirginleştiği, aynı kavram içinde örgülenen anlamsal birlikteliğe kavram alanı denir. Bir kavramın sınırlarını belirginleştirmek, eş deyişle bir kavramın diğer kavramlarla düşünsel mesafesini ortaya koymak, aynı zamanda o dilin düşünce deneyiminin yansıdığı kavram alanını belirlemek anlamına gelir. Bu bağlamda Ulmann (1978, s. 360), kavram alanının gelecek kuşaklar için bir dünya görüşünü (weltanschaung), bir değerler düzenini, yaşam felsefesini yansıttığını ve sağladığını savunur. Eş deyişle dilin dünyayı algılayışına, o dil kullanıcılarının dünya algısı siner. Bu bağlamda Humboldt'un ulusların dünyaya bakışının (weltansicht) dillerinden ayrı düşünülemeyeceği saptaması (Aksan, 2007, s. 21), daha da anlam kazanır. Kavram alanı, salt bir sözcük listesi değil; o dilin dünyaya bakışının, dünyayı algılayışının yansıdığı söz varlığı kesitidir. Görüldüğü gibi kavram alanı kuramı, yazıp konuşmada dilsel bir bütünlük sunduğu gibi o dilin dünyaya bakışını oluşturması ve yansıtması bakımından da ilgi çekicidir.

Trier'in aşağıdaki üç önermesi de kavram alanı kuramının temelini oluşturması bakımından dikkate değerdir:

i. Tek bir sözcügün anlamı, aynı sözlüksel veya kavramsal alandaki sözcüklerin geri kalanının anlamına bağlıdır.

ii. Tek bir kavram alanı, hiçbir boşluğun bırakılmadığı bir mozaik gibi inşa edilmiştir, bir dildeki kavram alanlarının tamamı, gerçekliğin özüne içkin bir fotoğraf yansıtır.

iii. Tek bir sözcügün anlamı değişirse, o zaman kavram alanının bütün yapısı değişir (Bussman, 2006, s. 674).

Yukarıdaki üç önermeden esinlenerek kavram alanıyla ilgili üç saptama ileri sürülebilir:

i. Bir sözcüğün anlamı, o sözcügün ait olduğu kavram alanındaki sözcükler hesaba katılmadan anlaşılamaz. Bir sözcüğe anlam biçmek, o sözcüğün kavramsal sınırlarını veya sinırsızlıklarını- ortaya koymak demektir.

ii. Sözcükler bir zincirin halkaları gibi birbirine bağlıdır. Kavram alanı birbiriyle ilişkili, çekişen; birbirini gerektiren, etkileyen besleyen sözcüklerin toplamının da ötesinde bir şeydir.

iii. Herhangi bir sözcüğün anlamı değiştiğinde, o sözcüğün ait olduğu kavram alanı yeniden inşa edilir. Bir sözcüğün birden fazla kavram alanına ait olabileceği göz önünde bulundurulduğunda, bu alana ait her sözcüğün değişiminde kavram alanları arası ilişki yeniden belirlenir.

Kavram alanı kuramı, özellikle soyut kavramların kültürel farklılıklarını belirleyebilmek için karşılaştırmalı dilbilim çalışmalarında merkezi bir konumdadır. Bu alandaki araştırmalarda "ayıp, günah, yakışıksız"; "adliye"; "onur, gurur, şeref"; "yağcılık"; "ironi"; "aile" kavramları; bu kuram çerçevesinde karşılaştırmalı olarak ele alınmıştır (Bkz. Avşar, 1998; Dikmen, 2013; Duman, 2013; Er, 2005; Gümüş, 1996; Kunt, 2007). Bununla beraber, okuma gibi disiplinler ve kültürler arası bir edimin de anlam sınırlarını ortaya koyabilmek için kavram alanı çözümlemesine gereksinim duyulur. Türkçe öğretmeni yetiştirmede önemli bir konu olan okuma eğitimi, belirli kavramlarla örgütlenerek işlenir. Bu kavramların belirlenmesi, okuma alanındaki sorunların da belirlenmesine ve çözülmesine yardımcı olabilir. 


\section{Çalışmanın amacı ve önemi}

$\mathrm{Bu}$ çalışmanın temel amac1, Türkçe öğretmeni yetiştirirken okuma eğitimi alanında sıklıkla kullanılan on kuramsal kitapta, ön plana çıkan okumanın kavram alanını saptamak ve tartışmaya açmaktır. Çalışma, bu temel amaç üzerine inşa edilmiştir.

Çalışmada, Almanya'da, Alman dili ve edebiyat dersinin gelişim tarihinin ele alındığ iki kaynak, yine okumanın kavram alanı bağlamında değerlendirilmiştir. Karşılaştırmalar, benzerliklerin ve farklılıkların belirginleşmesini sağlar. Almancadaki iki kaynak ile Türkçedeki on kaynağ , başka kültürden farklı bir bakış açısı sunmak amacıyla karşılaştırmak, bu çalışmanın alt amaçlarından biridir. Bu amaçla Türkçedeki kuramsal kaynaklarda ön plana çıkan kavramlarla Almancadaki kaynaklarda ön plana çıkan kavramlardan farklı olanlar üzerinde durulmuştur. Sadece farklı kavramların karşılaştırılmasının gerekçesi, okuma eğitimi alanındaki kavram gizil gücünün genişlemesine olanak sağlamaktır. Buradan hareketle, okumanın kavram alanının yeniden tartışılmasına ve ilgili kuramsal kitapların yeniden inşasına zemin hazırlamak amaçlanmıştır.

Çalışmada karşılaştırılan Türkçe eğitimi ile ilgili kaynaklar, Türkçe öğretmeni yetiştirme süreciyle ilgili bir içeriğe sahiptir. Almanca kaynaklar ise Alman dili ve edebiyatını ve tarihini konulaştırmaktadır. Her ne kadar Türkçe ve Almanca kaynaklar aynı amaçla kaleme alınmasa da, okuma eğitimine ilişkin birbirinden farklı kavramları barındırması bakımından karşılaştırmaya değerdir. Karşılaştırma yaparken bu farklılıklar, gözetilmiştir. Bununla beraber bu çalışmada karşıllaştırma yapmanın temel amacı, farklı kavramları belirginleştirerek okuma eğitimi çalışmalarına ufuk çeşitliliği sunmaktır.

Kuramsal kitaplarda okumayla ilgili hangi kavramların yoğunlaştığını, hangi kavramların ise göz ardı edildiğini tespit etmek; hem bu alanda okumaya ilişkin birikimi ortaya koyması hem de okuma eğitimindeki gereksinimlerin değerlendirilmesi bakımından önem taşımaktadır. Ayrıca okumanın kavram alanı bağlamında, başka kültürden kendi kültürümüze ayna tutmak, araştırmalarca da saptanan okuma ve anlama sorununun çözümüne katk1 sağlayabilir.

\section{Yöntem}

Disiplinler arası bir nitelik taşıyan bu araştırmanın yöntemi farklı şekillerde adlandırılabilir. Bir eğitim bilimi araştırması olarak betimsel niteliktedir ve çalışmada doküman analizi yöntemi kullanılmıştır. Dilbilim araştırması olarak çalışmada eşzamanlı bir artzamanlılık, artzamanlı bir eşzamanlılık gözetilerek "karşılaştırmalı kavram alanı çözümlemesi” yöntemi kullanılmıştır.

\section{Örneklem}

Türkçedeki okuma eğitimine ilişkin kuramsal kitaplar, bu çalışmanın evrenini oluşturmaktadır. Araştırmada okuma eğitimi alanında temsil yeterliliği olduğu düşünülen on kitap örneklem olarak incelenmiştir. İncelenen on ders kitabı belirlenirken temsil yeterliliği için Mersin Üniversitesi Eğitim Fakültesi Türkçe Eğitimi ve Eğitim Bilimleri bölümlerinde görev yapan iki öğretim üyesinin görüşüne başvurulmuştur. Türkçe okuma eğitimi alanında örneklem alınan kaynakların künye bilgileri aşağıda yer almaktadır:

- Akyol, H. (2009). Okuma. A. Kırkkılıç ve H. Akyol (Yay. haz.). Illköğretimde Türkçe ögretimi içinde (s. 15-48). Ankara: Pegem Akademi.

- Balc1, A. (2013). Okuma ve anlama eğitimi. Ankara: Pegem Akademi: Ankara.

- Demirel, Ö. (2004). Türkçe ve sını öğretmenleri için Türkçe öğretimi. Ankara: Pegem Akademi.

- Karahan, R. ve Yurdakul, H. İ. (2016). Okuma eğitimi. F. Susar Kırmızı (Yay. haz.). İlk ve ortaokullarda Türkçe öğretimi içinde (s. 107-162). Ankara: Anı Yayınları.

- Karatay, H. (2013). Okuma eğitimi: kuram, uygulama, ölçme ve değerlendirme. A. Güzel ve H. Karatay (Yay. haz.). Türkçe ögretimi el kitabı içinde (s.221-264), Ankara: Pegem Akademi. 
- Kavcar, C., Oğuzkan, F. ve Sever, S. (2005). Türkçe öğretimi Türkçe ve sinıf ögretmenleri için. Ankara: Engin.

- Öz, F. (2006).Uygulamalı Türkçe öğretimi. Ankara: Anı Yayınları.

- Şahin, Y. (2011). Okuma eğitimi. Konya: Eğitim Kitabevi.

- Yalçı, A. (2012). Türkçe öğretim yöntemleri yeni yaklaşımlar. Ankara: Akçağ.

- Yıldız, C. (2013). Okuma ve anlama öğretimi. C. Yıldız (Yay. haz.). Yeni öğretim programina göre kuramdan uygulamaya Türkçe ögrretimi içinde (s. 115-159), Ankara: Pegem Akademi.

Çalışmada, Türkçe kaynaklarla Almanca kaynaklar karşılaştırıldığı için, Almanca ve Alman edebiyatı dersinin gelişim tarihinin ele alındığı aşağıdaki iki kitap da incelemeye dâhil edilmiştir. Almanca kaynakları incelemek, bu çalışmanın temel amacı olmadığı için, inceleme iki kaynakla sınırlandırılmıştır:

- Bogdal, K. M. ve Korte, H. (2006). Grundzüge der literatur-didaktik (Edebiyat ögretbiliminin temelleri). München: Deutscher Taschenbuch Verlag.

- Paefgen, E. K. (2006). Einführung in die literaturdidaktik (Edebiyat ögretbilimine giriş). Stutgart: Verlag J. B. Metzler.

\section{Verilerin toplanması ve analizi}

Örneklem alınan kuramsal kitaplarda ön plana çıkan kavramlar, yarı yapılandırılmış gözlem formu aracılığıyla sınıflandırılmış ve bulgular bölümünde örneklendirilerek açıklanmıştır. Söz konusu kaynaklarda okuma ile ilgili çok sayıda kavrama rastlamak olanaklıdır. Bu nedenle incelenen kitaplarda ayrıntılı bir biçimde ele alınan ve bütün kitapların ortaklaştığı kavramlar; okuma eğitiminin kavram alanı olarak belirlenmiş ve örneklendirilmiştir.

\section{Bulgular}

Her düşünce, o düşünceye ilişkin kimi kavramlar çerçevesinde düzenlenir. Kavram alanı kuramı, belirli düşüncelerin belirli kavramlarla anlam kazandığı ilkesine dayanır. Bu bağlamda düşünce, bir bakıma kavram seçkisidir. Eş deyişle düşünce, kavramsal bir yeğleyiştir. Her yeğleyiş de bir vazgeçiştir. Okuma eğitimine ilişkin kuramsal kitaplarda da düşünceler düzenlenirken belirli kavramlar ön plana çıkmakta, belirli kavramlar ise geri planda kalmaktadır. İncelenen on kuramsal kitapta ön plana çıkan kavramlar şu başlıklar altında sınıflandırılmıştır: fizyolojik kavramlar, fiziksel kavramlar, alışkanlık, hız, metin, bilgi, kelime hazinesi, sosyallik ve anlama. Bu kavramlar örneklendirildikten sonra Almanca kaynaklarda okumanın hangi kavramlarla örgülendiği ele alınmıştır.

\section{Fizyolojik kavramlar}

İncelenen kuramsal kaynakların neredeyse tamamında, diğer özelliklerine geçmeden önce, okumanın fizyolojik temeli açıklanmıştır. Bu nedenle duyu organları, beyin, göz, göz kasları, netlik alanı, aktif görme alanı, netlik açısı, okuma mesafesi, sıçrama, duraklama, görme kusurları, okuma güçlüğü, renk körlüğü, şaşılık, kekemelik, ses, ses telleri, hançere, dudak, dil gibi fizyolojik kavramlar, incelenen kaynaklarda sıkça yer almıştır. Diğer dil becerilerinde olduğu gibi, okumanın da fizyolojik özellikleri, okuma ediminin kazandırılması ve geliştirilmesinde çok önemlidir. Bu özelliklerin bilinmesi, öğretmenlerin nitelikli bir okuma eğitimi vermeleri için ilk adımı oluşturur. Bu nedenle okumanın fizyolojik özelliklerinin belirginleştirilmesi doğal ve yararlıdır. Ancak okuma fizyolojik kavramlara sığdırılamayacak kadar çok bileşenli bir beceridir. Salt fizyolojik özellikler, okuma eğitimini sınırlandırır.

Aşağıdaki bölümler, okuma eğitimine ilişkin kuramsal kitapların fizyolojik kavramlarla inşa edilmesine örnek gösterilebilir.

- "Görme organlarının sağlığı, doğal olarak okumanın temel basamaklarını sağlamada da önem taşımaktadır” (Balc1, 2013, s. 7). 
- $\quad$ "Okuma eyleminde ses yolunun da önemi çoktur. Hançere, dil, dudak seslendirmede görevlidir. Vurguları doğru ya da yanlış yapmak, tonlamayı tam ya da eksik uygulamak işitme organına dayanır" (Yıldız, 2013, s. 116).

- "Okurken göz bir yazıdaki harf ya da sözcükleri teker teker görmez; sıçrama ve duraklamalar yaparak sözcükleri ya da sözcük kümelerini bir bütün olarak görür" (Kavcar, Oğuzkan ve Sever; 2005, s. 41).

- Gözümüz bir kâğıt üzerindeki herhangi bir yazıya baktığı zaman göz kaslarımız göz sinirlerimizin uyarması ile gözümüze 13-19 derecelik bir açı yaptırmaktadır. Bu açı ile iki gözümüz kâğıt üzerindeki bir alanı net bir biçimde görmektedir. Bu açıya netlik alanı adını veriyoruz" (Yalçın, 2012, s. 49).

- "İyi bir okumada ses veya seslerin doğru bir şekilde algılanması oldukça önemlidir. Seslerin doğru tanınması ise işitme ve görmeyle yakından ilgilidir” (Akyol, 2009, s. 15).

\section{Fiziksel kavramlar}

Okuma eğitimi, fizyolojik kavramların yanı sıra, kimi fiziksel ögelere de dayanır. Buna koşut olarak kitap, kitaplık, sınıf kitaplığı, kâğıt, birinci hamur, 1şık, 1şık yönü, yazı, el yazısı, yazı karakteri, punto, resim, görsel, fotoğraf, renk, sayfa, satır boyu, cm, yazı, grafik, desen, matbaa gibi fiziksel kavramlar, incelenen kuramsal kitaplarda sıkça yer almıştır.

Okumanın belirli bir nesneye yönelik olma zorunluluğu, okumanın fiziksel yönünü oluşturur. $\mathrm{Bu}$ nedenle, okuma eğitimine ilişkin kuramsal kitaplarda okumanın fiziksel yönü, anılan kavramlarla yapılandırılmıştır. Bununla beraber, okumayı sadece fiziksel yönüyle ele almak bir eksikliktir. Çünkü okuma, fiziksel özelliklerin ötesinde bilişsel ve düşünsel derinliği olan bir edimdir.

Ders kitaplarından alınan aşağıdaki bölümler, okumanın fiziksel kavramlarla organize edilmesine örnek gösterilebilir.

- "Algılamada kitap kâğıdının kalitesi, okuma anında 1şığın geliş yönü önemli etki yapmaktadır. Yapılan araştırmalarda kâğıdın birinci hamur ve 1şığı yansıtmayacak, arkasını göstermeyecek özelliklerde olması gerekmektedir. Sınıfın aydınlatılmasının çocukların okumasını kolaylaştırmak amacıyla ya tepeden veya soldan gelmesinin okuma eğitimini sağlıklı bir biçimde etkileyeceği ortaya çıkmıştır" (Yalçın, 2013, s. 52).

- "Kitaplarda yazı karakteri ve puntosu yanında özellikle okumaya yeni başlayan ve ilerletme aşamasında olan çocuklar için sayfa düzenlemesine özel bir önem verilmesinin okumaya ilgiyi artıracağı tespit edilmiştir" (Yalçın, 2012, s. 50).

- "Okurken önce yazıdaki görsel simgeler yani kelimelerin şekilleri tanınır” (Balcı, 2013, s. 6).

- “Okunacak ilkyazı, eğer çocukların ön deneyimlerini göz önünde tutacak olursak, matbaa harflerinden oluşan yazı olmalıdır. Nitekim okuma tekniği bakımından matbaa harflerinin el yazısından daha okunaklı olduğu bilinmektedir" (Yıldız, 2013, s. 122)

- Öğretmen, okuma öncesi öğrencinin hangi tür (dünya, kitaplar, olaylar vb.) ön bilgiye ihtiyacı olduğunu tespit ederek bu ihtiyacı gidermeye çalışmalıdır. Bu süreçte öğretmen görsellerden, konuşmalardan, kitaplardan vb. yararlanabilir" (Akyol, 2009, s. 25).

\footnotetext{
Alışkanlık

Okuma eğitimine ilişkin kuramsal kitaplarda yoğun olarak kullanılan kavramlardan biri de "alışkanlık"tır. "Okuma alışkanlığı" kavramı, bu alanda yapılan akademik araştırmalarda da sıklıkla kullanılmaktadır (Bkz. Aksaçlıoğlu ve Yılmaz, 2007; Arslan, Çelik ve Çelik; 2009; Konan, 2013; Odabaş, Odabaş ve Polat; 2008; Yılmaz, 1989; Tanju, 2010).

Alışkanlık "İç ve dış etkilerle hep aynı biçimde gerçekleşmesi sonucu beliren şartlanmış davranış" (TDK, 2011, s. 95) olarak tanımlanmaktadır. "Okuma alışkanlığı" kavramı, okumanın bireysel ve özgür yanını vurgulamadığı için eleştiriye açıktır. Okuma, şartlanma sonucu oluşacak bir eylem değil; tersine özgür istençle gerçekleştirilecek etken bir süreçtir. Bu nedenle okuma, alışkanlığa indirgenemez. Okumayı alışkanlıklaştırmak, okumanın gerektirdiği özgür
} 
bilinç ve istenci görmezden gelmek anlamına gelebilir. Bu bağlamda son zamanlarda akademik çalışmalarda, okuma alışkanlığı yerine okuma kültürü, okuma ilgisi, okuma tutumu gibi kavramların kullanıldığı göze çarpmaktadır. Ancak bu çalışmada incelenen kuramsal kaynaklarda "okuma alışkanlığı" kavramı, okuma eğitimi için önemli bir kazanım olarak ifade edilmeye devam etmiştir. Aşağıdaki bölümler, bu bulguyu örnekler niteliktedir:

- "Okuma alışkanlığının kazanılması, birçok zihinsel becerinin de etkin kullanımını sağlar" (Balcı, 2013, s. 2).

- "Okuldan sonra da öğrendiklerini unutmaması, öğrendiklerine yeni bilgiler katması okuma alışkanlığı kazanmasına bağlıdır. Okuma alışkanlığı ise ancak serbest okumalarla kazanılabilir" (Öz, 2006, s. 217).

- "Aile içindeki bireylerin kültür düzeyleri, okuma alışkanlıkları çocuk üzerinde etki birakır" (Demirel, 2004, s. 77).

- "Öte yandan, öğretim büyük ölçüde okumaya dayanır. Başka bir deyişle, hemen hemen bütün dersler, iyi bir okuma becerisi ve alışkanlığı kazanmış olmayı gerektirir (Kavcar, Oğuzkan ve Sever; 2005, s. 41).

- "Aile içindeki bireylerin kültür düzeyleri, okuma alışkanlıkları çocuk üzerinde etki birakır" (Yıldız, 2013, s. 116).

- "Çocukta okuma eğitimi 15 yaşının sonuna kadar planlı ve sürekli bir biçimde yapıldıktan sonra okuma alışkanlığı oluşur" (Yalçın, 2012, s. 50).

- "Okuma alışkanlığının kazandırılması ve okuma hevesini artırmada, aile içinde, okul genelinde, halka açık kütüphanelerin özel salonlarında ve kültür merkezlerinde her yaştan ve her meslek grubundan kimselerin katılabileceği okuma günleri ve okuma geceleri düzenlenebilir"' (Şahin, 2011, s. 9).

\section{Hız}

Alışkanlıkla beraber, "okuma hızı" da ilgili kitaplarda yoğun olarak kullanılan kavramlardan biridir. Okuma hızı, okumanın yeni öğrenildiği aşamalarda anlamayı kolaylaştırması bakımından vurgulanabilir. Ancak salt hıza dayalı okuma, tat almayı göz ardı eder. Aynı zamanda hızlı okuma, daha çok metin tüketimini çağrıştırır. Oysa okuma, metin tüketmekten çok metin ve anlam üretmeyi; harcamaktan çok anlam biriktirmeyi içerir. Vurgulanması gereken bir başka nokta da şudur: Okuma, hıza kurban edilirse; tat alma ve olgunlaşma ihmal edilir. Başka bir deyişle hıza tutsak olmuş bir okuma, okumayı araçsallaştırır. Okuma bir araç değil, başlı başına bir amaçtır. Okunandan tat almak da hızdan bağımsızdır; bu nedenle hızdan çok "anlam, zevk, üretim, birikim" kavramları ön plana çıkarılmalıdır.

Okuma eğitimine ilişkin kuramsal kitaplarda hız kavramı, okumanın temel ögelerinden biri olarak betimlenmiştir. Aşağıdaki bölümler, bu bulguyu örneklemektedir:

- "Okumanın asıl amacı, yazılı malzemede sunulan anlamı doğru ve hızlı bir şekilde kavramaktır" (Balc1, 2013, s. 6).

- "Okuma hızını hesaplama yollarından birisi de dakikada okunan kelime sayısının belirlenmesiyle ilgilidir. Okunan kelime sayısı dakika sayısına bölününce okuma hızı belirlenebilir" (Akyol, 2009, s. 39).

- "Yapılan araştırmalar, göz ne kadar hızlı hareket ederse etsin beynin çalışma ve kavrama hızına asla ulaşamayacağını ortaya çıkarmıştır" (Yalçın, 2012, s. 56).

- Bunun için özellikle birinci sınıflarda okuma parçaları, kelimeler yönünden, birbirine dayalı olursa öğrencilerin parçayı ezberlemeden okumaları ve böylece okuma hızını doğa yoldan artırmaları mümkün olur" (Öz, 2006, s. 211).

- "Gözün, sözcük biçim ya da kalıplarına alışı olduğu durumlarda duraklama ve sıçramalar arasındaki süre azalır; böylece okuma hızı artmış olur” (Kavcar, Oğuzkan ve Sever; 2005, s. 42).

- "Okuma öncesinde okuma hızını belirleme, metni gözden geçirme, ön bilgilerini harekete geçirme, belli aralıklarla durup ne anladığını denetleme / izleme gibi kendi kendini kontrol ve değerlendirme farkındalığı olan okurların, iyi kavrayıcılar olduğu belirlenmiştir (Karatay, 2013, s. 230). 


\section{Metin}

İncelenen kitaplarda ön plana çıkan kavramlardan bir diğeri de “metin"dir. 1960'l1 y1llardan bu yana metin dilbilimdeki gelişmeler, metin odaklı dil eğitimine zemin hazırlamıştır. Metin odaklı dil eğitimi; metin üretimine ve metin alımlamaya dayanır. Diğer becerilerde olduğu gibi, okuma becerisinin geliştirilmesinde de metinlerden yararlanmak kaçınılmazdır. Her okuma, metne yöneliktir; bir başka deyişle her okuma, aslında bir metin okumadır. Eş deyişle her okuma, metne karşı bir tutum alıştır. Bu bakımdan okuma türü veya stratejisi, metin türüne göre farklılaşır. Bu nedenle okuma eğitiminde "metin" kavramı önemli bir yer tutar. Aşağıdaki bölümler, okuma eğitiminde "metin" kavramının kullanımına örnek gösterilebilir:

- "Okuma eğitiminin temel amacı, okuduğunu kavrayan, sorgulayan, kavradığına doğru tepkide bulunabilen ve bu becerileri okunan her metne karşı bilinçli ve etkin bir şekilde kullanabilen bireyler yetiştirmektir" (Karatay, 2013, s. 225).

- "Öğretmen sınıfa getirdiği metnin kaliteli olup olmadığını sürekli olarak kendisine sormalıdır" (Yalçın, 2012, s. 63).

- "Öğretmen farklı metinlerin okunmasına nasıl başlanacağını iyi bilmelidir" (Akyol, 2009, s. 24).

- "Öğrenciler belli bir metni küme arkadaşlarına ya da belli bir gruba okumalıdır" (Demirel, 2004, s. 81).

- "Metin anlama becerisi de, çok yönlü metin çalışmalarıyla desteklenebilir" (Yıldız, 2013, s. 117).

\section{Bilgi}

"Bilgi çağı" olarak nitelenen zamanımızda insan, yoğun bir bilgi bombardımanına maruz kalmaktadır. Bu bilgi çokluğu, gelişmeyi sağlamasının yanında bilgi kirliliğine ve buna dayalı güdümlemeye (manipülasyon) yol açabilmektedir. Artık bilgiye ulaşmak kadar, bilgiyi içselleştirmek de önem kazanmıştır. Bu nedenle bilgiyi ayıklamak, değerlendirmek ve işlevsel hale getirmek, günümüz insanı için bir zorunluluğa dönüşmüştür.

Bilgiyle başa çıkabilmek için, okuma temel becerilerden biridir. Bu nedenle okuma eğitiminin kavram alanında "bilgi" de yer almaktadır. Aşağıdaki bölümler, bu bulguyu örnekler niteliktedir:

- "Dört temel dil becerisi içinde okuma, temel bilgi edinme vasıtası olması yönüyle bireylere hayat boyu sürecek bir öğrenme sürecinin kapılarını açmaktadır" (Balcı, 2013, s. 2).

- "Ön bilgiler, öğrencinin metinden çıkarımlar yapmasına ve metni analiz etmesine katkı sağlamaktadır" (Akyol, 2009, s. 25).

- CCünkü yetişmekte olan bir kişi, çok daha geniş ve zengin bilgi kaynaklarına erişmek, bu kaynaklardan kendi ihtiyacına göre yararlanmak ister. Bu da ancak okuma ile olabilir" (Kavcar, Oğuzkan ve Sever, 2005, s. 41).

- "Gelişmeleri izleme, yeni bilgilere ulaşma, kendini yineleme yollarından birisi, belki de en önemlisi iyi bir okuma ve kavrama becerisidir. Okuduğunu kavrama, bilgiye hızlı ulaşmanın, onu içselleştirme çabası olan öğrenmenin temel koşuludur”' (Karatay, 2013, s. 221).

- "Öğretmen okuma eğitimine başlamadan önce ustalıkla bu ön bilgileri çocuğa vererek onu hazırlamalı, daha sonra okumaya yönelmelidir" (Yalçın, 2012, s. 65).

- "Bir toplumun yaşayış biçimi hakkında ya geride bıraktığı eserleri yorumlama veya yazılı kaynakları çözümleme yoluyla bilgi edinilebilir. Yazılı kaynakları çözümleme de, okuma eğitimini gerekli kılmıştır” (Şahin, 2011, s. 2)

\section{Kelime hazinesi}

Kelime hazinesi diğer tüm hazinelerden daha kullanışlıdır. Çünkü hazineler harcandıkça azalır; oysa kelime hazinesi harcandıkça çoğalır (Kanatlı, 2013, s. 735). Bu bağlamda okuma eğitimi, kelime hazinesinin harcandıkça çoğaldığı alanlardan biri olmalıdır. Okuma becerisi, öğrencilerin kelime ve hissetme hazinesinin gelişmesine zemin hazırlayabilir. Kelime hazinesi, 
hissetme ve düşünme hazinesine eşlik etmezse veya tersi, anlamak ve anlamlandırmak güçleşir. Kelime hazinesi ve okuduğunu anlama becerisi, birbirini besleyen, birbirini eşgerektiren alanlardır. Kişi, ancak okursa kelime hazinesi gelişir, ancak kelime hazinesi gelişkin bireyler okumaktan tat alır. Bu nedenle okuma eğitiminde kelime hazinesini vurgulamak doğaldır.

Öğrencilerin kelime hazinesini geliştirebilmek için, okuma eğitimi vazgeçilmez bir beceridir. Bu görüşe koşut olarak okuma eğitimine ilişkin kuramsal kitaplarda "kelime hazinesi" kavramına yer verildiği gözlenmiştir. Aşağıdaki bölümler, bu saptamaya örnek verilebilir:

- "İleri yaşlarda ise okumada belirli bir düzeye gelen öğrenciye verdiğimiz okuma metinlerinde anlamını bilmediği ve öğrenmesi kendisine gerekli olan kelimeler özellikle verilmelidir" (Yalçın, 2012, s. 58).

- "Okuma anında bilinmeyen kelimeler altı çizilerek veya renklendirilerek belirlenmeli ve daha sonra bu kelimelerin metin içerisindeki anlamları öğrenilmelidir" (Akyol, 2009, s. 32).

- "Öğrencilere bilinmeyen sözcükleri az, düşünce ve duygu yönünden yalın yazılar okutulmalıdır" (Demirel, 2004, s. 81).

- "Öğrencilerin sözcük dağarcıkları zenginleştirilmelidir” (Demirel, 2004, s. 81).

- "Türkçe derslerinde yapılan farklı türlere dayalı okuma eğitimi etkinlikleri ile öğrencilerin söz varlığı, dili kullanma becerileri, metin kavrama stratejileri ve teknikleri edinmeleri sağlanır, ayrıca okuma alışkanlıkları ve ilgileri de geliştirilmeye çalışılır (Karatay, 2013, s. 234).

\section{Sosyallik}

Okuma, diğer kazanımlarının yanı sıra bir sosyalleşme süreci olarak da kabul edilmektedir. İncelenen kaynaklarda üzerinde durulmamasına rağmen, "okuma sosyalleşmesi" okuma eğitiminin önemli hedeflerinden biridir. Bu nedenle okuma ile sosyallik arasındaki yoğun ilişki, bu alandaki kuramsal kitaplarda derinleștirilmelidir.

İncelenen kitaplarda çok ayrıntıya girilmese de okumanın sosyal yönü de ele alındığı belirlenmiştir. Aşağıdaki bölümler, bu saptamaya örnek gösterilebilir.

- "Okuma eğitimi çocukların kendisinden başlayarak dişa doğru, sosyal problemleri anlayacak, yorumlayacak düzeyde yapılmalıdır” (Yalçın, 2012, s. 61).

- "Bugün dil öğretimi alanında hazırlanan kitaplara zaman zaman "Hayat Bilgisi", "Sokak Bilgisi” gibi adların verildiğini görüyoruz" (Yalçın, 2012, s. 61).

- "Okuma ne kadar bireysel bir etkinlik olarak değerlendirilirse değerlendirilsin, bireyin içinde yaşadığı toplum da düşünüldüğünde aynı zamanda toplumsal bir etkinliktir” (Balc1, 2013, s. 11).

- "Okuma bireysel bir etkinlik olmaktan çok, toplumla da ilgilidir. Bireyler topluma uyabilmek için okurlar. Okuma, toplumun uygarlaşmış olmasına da bağlıdır" (Demirel, 2004, s. 78).

- Kişi belli bir kültür düzeyinde eğitildiği için, içinde bulunduğu çevrenin varlığı çok önemlidir. Okuma eğitiminin gelişiminde aile bireylerinin önemli etkisi vardır" (Yıldız, 2013, s. 116).

\footnotetext{
Anlama

İster görev odaklı ister tat almak için olsun, okumanın hem zemini hem de sonucu anlamadır. Anlama ediminden yalıtılmış bir okuma, okumanın gerçek amacına hizmet edemez. Bu doğrultuda, incelenen kitaplarda okumanın kavram alanında anlamaya da yer verildiği gözlemlenmektedir.

Çalışmanın başında belirtildiği gibi, 2015 yılındaki PISA sonuçları, birbirini besleyen iki temel sorunu gündeme getirmiştir: i) Türkiye'de az kitap okuma sorunu vardır, ii) Türkiye'de okuyanların da okuduğunu anlama sorunu vardır. Dolayısıyla bu sorunu gidermek için anlama, okumanın merkezinde yer almalı; okuma eğitimi, anlamaya dönük olmalıdır.

Okul sıralarında öğrenciler, anlama ve anlamlandırma deneyimini yaşantılamalıdır. Okuma eğitimi, öğrencilerin kendini ve hayatı anlamasına zemin oluşturacak etkinliklerle
} 
beslenmelidir. Bu bakımdan sesletim odaklı okumanın ötesinde anlama odaklı okuma becerisi, kuramsal kitaplarda daha ayrıntılı bir biçimde ele alınmalıdır.

İncelenen kuramsal kitaplarda anlamaya ilişkin kimi bölümler aşağıda yer almaktadır:

- "Okuduğunu anlama sürecinde anlamı bulma, anlam üzerinde düşünme, nedenleri araştırma, sonuçlar çıkarma ve değerlendirmede bulunma vardır” (Balcı, 2013, s. 14).

- "Okunandan anlam kurma farklı unsurlara bağlıdır. Okuma türü, okumanın konusu, okuyucunun fiziksel ve zihinsel durumu anlam kurmayı etkileyen bazı faktörlerdir" (Akyol, 2009, s. 32).

- Anlamlı okuma, bir parçayı, anlatılanı belirterek zevkli bir şekilde okumak demektir. Böyle bir okuma sırasında parçanın neşeli, üzüntülü, hareketli vb. yerleri sesle belirtilmelidir" (Öz, 2006, s. 213).

- 'İki ayrı çaba gibi görünen 'okuma ve anlama' aslında birbirine neden-sonuç ilişkisi ile bağlıdır. İnsan anlamak için okur. Okuduğunu da anlamak ister” (Demirel, 2004, s. 83).

- "Aslında sadece çok basit metinler okunurken anlamları kendiliğinden çıkmaktadır. İyi yazılmış ve daha zor metinlerde ise anlam sürekli değişik ve yeni boyutlar kazanabilmektedir" (Y1ldı, 2013, s. 129).

- "Okuduğunu anlama, okurun metinle amaçli ve bilinçli bir etkileşim kurmasına dayanan süreçtir" (Karatay, 2013, s. 223).

\section{İki Almanca kaynakta okumanın kavram alanı}

Çalışmanın bu bölümünde Almanya'da, Alman dili ve edebiyat dersinin gelişim tarihinin ele alındığı iki kuramsal kaynak, yine okumanın kavram alanı bağlamında değerlendirilmiştir. Daha önce söylendiği gibi karşılaştırmalar, benzerliklerin ve farklılıkların belirginleşmesini sağlar. Benzerlik ve farklılıkların belirginleşmesi ise kültürel gelişim ivmesini hızlandırır. Bu nedenle, başka kültürlere açılım, başka kültürden öz kültüre ayna tutma; eğitimsel süreçleri olumlu açılardan devindirebilir.

"Grundzüge der Literaturdidaktik" adlı kitapta (Bogdal ve Korte, 2006), okuma eğitiminde ön plana çıkan kavramlar, birbiriyle ilişkilerine göre aşağıdaki gibi sıralanabilir:

- Okuma eylemi, okuma yetisi, okuma deneyimi, okuma yapılandırmas1, okuma olgunluğu, okuma tutumu, okuma iklimi

- Okuma sosyalleşmesi, yazınsal sosyalleşme, yazınsal özsosyalleşme, yazınsal iletişim, sosyal ve iletişimsel katılım

- Alımlama estetiği, alımlama olanakları, estetik deneyim

- Çokkültürlülük, çokdillilik, kültürlerarası iletişim ve etkileşim

- Ö̈zerklik, özerkleştirici ben gelişimi, kendini gerçekleştirme, birey olma

- Ufuk açma, ufuk geliştirme

- Eleştirel okuma, eleştirme yeteneği, yaşamın bir eleştirisi olarak okuma

- Metin ve okur etkileşimi olarak okuma

- Yaşam boyu öğrenme süreci olarak okuma, yaşantılamaya açıklık

- Kavram oluşturma ve düşünce oluşturma olarak okuma

- Toplumun kültürel belleği olarak okuma

- Düşünme ve anlama alışkanlıklarının sarsılması olarak okuma

- Anlam oluşturucu olarak okur, anlama, anlamlandırma, özanlama, başkayı anlama

- Empatik okuma

- Okuma öznesi

- Düşünsel gelişim

$\mathrm{Bu}$ başlık altında incelenen ikinci kitap "Einführung in die Literaturdidaktik"te (Paefgen, 2006), okuma becerisine ilişkin ön plana çıkan kavramlar, birbiriyle ilişkilerine göre aşağıdaki gibi sıralanabilir:

- Okuma dinamiği, okuma heyecanı, okuma coşkusu, okuma sevinci, okuma eğlencesi, okuma motivasyonu, okuma iklimi 
- Düşünme, şiirsel düşünme, ürün odaklı düşünme, üretim odaklı düşünme, tarihsel odaklı düşünme

- Anlama, anlamlandırma, üst düzeyli anlama olarak okuma

- Kendi deneyim ufuklarıyla yüzleşme olarak okuma

- Kimlik/kişilik geliştirici/güçlendirici bir süreç olarak okuma

- Bir özgürlük yaşantısı olarak okuma

- Protesto ve karşı çıkmanın özendirilmesi olarak okuma

- Keşfetme sevinci, keşfetme zevki, keşfetme tadı

- Yazınsal sosyalleşme, okuma sosyalleşmesi

- Tasarım, çağrışım

- Öngörü, önsezi

- Duygusal yönelim, entelektüel yönelim

- Eleştiriyi özendirici okuma, eleştirel okuma, özeleştirel okuma

- Yaşam desteği olarak edebiyat dersi, yaşamın içinde okuma, dünyadaki yaşamın üstesinden dille gelmek

- Alımlama estetiği, estetik değer

- İnsanlaşma, birey olma

\section{Sonuç ve Öneriler}

Türkçe öğretmeni yetiştirirken okuma eğitimi alanında sıklıkla kullanılan on kuramsal kitapta ve Almanya'da, Alman dili ve edebiyat dersinin gelişim tarihinin ele alındığ iki kaynakta ön plana çıkan okumanın kavram alanı saptamayı ve tartışmayı amaçlayan bu çalışmada ulaşılan sonuçlar aşağıdaki gibi sıralanabilir:

- Türkçe kaynaklarda ön plana çıkan kavramlar şunlardır: fizyolojik kavramlar, fiziksel kavramlar, alışkanlık, hız, metin, bilgi, kelime hazinesi, sosyallik ve anlama.

- Almanca kaynaklarda Türkçe kaynaklardan farklı olarak ön plana çıkan kimi kavramlar ise şunlardır: okuma sosyalleşmesi, yazınsal sosyalleşme, alımlama estetiği, metin ve okur etkileşimi, özerklik, birey olma, kimlik/kişilik geliştirici/güçlendirici bir süreç olarak okuma, öz eleştirel okuma, okuma dinamiği, okuma heyecanı, okuma coşkusu, okuma iklimi, okuma motivasyonu, okuma deneyimi, okuma yapılandırması, bir özgürlük yaşantısı olarak okuma, düşünme ve anlama alışkanlıklarının sarsılması olarak okuma...

- Türkçede incelenen on kaynakta dokuz; Almancada incelenen iki kaynakta ise onlarca kavram saptanmıştır. Bu durum, Almancadaki kuramsal kitapların kavram yoğunluklu oluşturulduğunu göstermektedir. Bu sonuç, Türkçe ve Almanca kaynakların farklı amaçlarla kaleme alınmasından ileri gelebilir. Ancak yine de dikkate değerdir.

- $\mathrm{Bu}$ araştırmada okuma eğitimi ile ilgili Türkçe kaynakların daha somut, Almanca kaynakların ise daha soyut kavramlarla örgülendiği açığa çıkmaktadır. Soyut kavramlar düşünmeyi özendirir, yeni düşüncelere kap1 aralar. $\mathrm{Bu}$ nedenle Almancadaki kaynakların Türkçe kaynaklara göre okuma üzerine kafa yormayı daha çok özendirdiği söylenebilir.

- Türkçe kaynaklarda okuma bir alışkanlık olarak ele alınmakta fakat Almanca kaynaklarda düşünme ve anlama alışkanlıklarının sarsılması olarak ifade edilmektedir. $\mathrm{Bu}$, okuma alışkanlığı kavramını sorgulamak için önemli bir karşılaştırmadır.

- Türkçe kaynaklarda alımlama estetiğine rastlanmamıştır. Oysa Almanca kaynaklarda alımlama estetiği, okuma eğitimi için temel kavramlardan biridir.

- Türkçe kaynaklarda edebiyat ve edebiyata içkin kavramlar yeterince vurgulanmamıştır. Okuma ve edebiyat arasında dolaysız bir bağ vardır ve bu bağ, okuma eğitiminde ele alınmalidır.

- Almanca kaynaklarda okuma, anlama ve düşünme ilişkisi, kavramsal bir birliktelik içinde Türkçe kaynaklara göre daha yoğun olarak vurgulanmıştır. 
- Almanca kaynaklarda "özerklik, özerkleştirici ben gelişimi, kendini gerçekleştirme, birey olma, bir özgürlük yaşantısı olarak okuma” gibi kavramlara rastlanmaktadır. Türkçe kaynaklar, okumanın özerkleştirici ve özgürleştirici yanını ihmal etmiştir.

Okuma eğitimi üzerine yazılan kuramsal kaynaklar, bu alandaki düşünsel ve akademik birikimi ortaya koyduğu gibi, öğretmenlerin uygulamalarına da ş̧ık tutmaktadır. Dolayısıyla çeşitli düzlemlerde gerçekleştirilen okuma-anlama sınavlarında elde edilen başarı, okuma eğitimi alanındaki kuramsal kaynakların kavram alanından bağımsız değildir. Bu nedenle okuma eğitimi alanındaki kuramsal kaynakları gözden geçirmek, okumayı belli başlı kavramlarla sınırlamamak, yeni kavramlarla okumanın kavram alanını genişletmek gerekir. Bu anlamda, okuma eğitiminde başarılı sonuçlar elde eden ülkelerin kuramsal kaynakları incelenebileceği gibi, özgün kavramlar da tartışmaya açılabilir.

Okuma sosyalleşmesi, yazınsal sosyalleşme, yazınsal özsosyalleşme, yazınsal iletişim gibi kavramlar; Türkçede okuma eğitimi tartışmalarına ufuk çeşitliliği sunabilir. Okuma eğitimi alanındaki akademik çalışmalarda, "kavram tartışmaları" gereksinimi kendini duyumsatmaktadır. $\mathrm{Bu}$ doğrultuda Türkçede okuma eğitimine ilişkin kuramsal kaynakların yenilenmesi, düşünmeyi özendiren kavramlarla yeniden inşası yararlı olabilir.

\section{Kaynaklar}

Aksaçlıŏglu, A. G. ve Yılmaz, B. (2007). Öğrencilerin televizyon izlemeleri ve bilgisayar kullanmalarının okuma alışkanlıkları üzerine etkisi. Türk Kütüphaneciliği, 21(1), 3-28.

Aksan, D. (1971). Kelimebilimi ve anlambilimi ölçülerinden yararlanarak bir yazı dilinin eskiliğini saptama yolları 1: kavram alanı-kelime ailesi ilişkileri ve Türk yazı dilinin eskiliği üzerine. Türk Dili Araştırmaları Yıllı̆̆ Belleten, 338, 253-262.

Aksan, D. (2007). Her yönüyle dil ana çizgileriyle dilbilim. Ankara: TDK Yayınları.

Aksan, D. (2016). Anlambilim anlambilim konuları ve Türkçenin anlambilimi. Ankara: Bilgi Yayınevi.

Arslan, Y., Çelik, Z. ve Çelik, E. (2009). Üniversite öğrencilerinin okuma alışkanlığına yönelik tutumlarının belirlenmesi. Pamukkale Üniversitesi Eğitim Fakültesi Dergisi, 26, 113124.

Avşar, G. S. (1998). Ayıp, günah, yaklşıksız kavramlarının Almancada ve Türkçede karşılaştırılması (Yayımlanmamış Yüksek Lisans Tezi). Hacettepe Üniversitesi Sosyal Bilimler Enstitüsü, Ankara.

Bussman, H. (2006). Routledge dictionary of language and linguistics, G. P. Trouth ve K. Kazzaz (Çev.). Londondand New York: Routledge.

Dikmen, Ç. C. (2013). Almanca ve Türkçede 'adliye' kavramı anlam alanı -sözcükbilime ve anlambilime dayalı dil analizine yönelik karşılaştırmalı bir çalışma (Yayımlanmamış yüksek lisans tezi). Hacettepe Üniversitesi Sosyal Bilimler Enstitüsü, Ankara.

Duman, E. (2013). Almanca ve Türkçedeki 'onur', 'gurur', 'şeref' anlam alanlarının karşılaştırılması sözlükbilim, sözcükbilim ve anlambilim üzerine karşılaştırmalı bir çalışma (Yayımlanmamış yüksek lisans tezi). Hacettepe Üniversitesi Sosyal Bilimler Enstitüsü, Ankara.

Er, M. (2005). Türkçe ve Almancada 'yağcllık' kavram alanı sözcükbilim ve anlambilim üzerine karşıllaştırmalı bir çalışma (Yayımlanmamış yüksek lisans tezi). Hacettepe Üniversitesi Sosyal Bilimler Enstitüsü, Ankara.

Eziler Kıran, A. ve Kıran, Z. (2011). Yazınsal okuma süreçleri. Ankara: Seçkin.

Gümüş, N. (1996). Almanca ve Türkçedeki ironinin anlam alanı ve ironiye benzer terimler (Yayımlanmış yüksek lisans tezi). Hacettepe Üniversitesi Sosyal Bilimler Enstitüsü, Ankara.

Kanatlı, F. ve Çekici, Y. E. (2011). Nermi Uygur penceresinden okuma sorunsalına felsefi bir yaklaşım. 11. Uluslararası Dil-Yazın-Deyişbilim Sempozyumu 13-14 Ekim 2011, Sakarya, Bildiriler içinde (s. 275-287). Sakarya: Sakarya Üniversitesi. 
Kanatlı, F. (2013). Temel sözvarlığı bağlamında Türkçede ve Almancada en sık kullanılan elli eylemin söz-eylem kuramı çerçevesinde dil-yapısal ve kültürel açıdan karşılaştırılması. Turkish Studies. 8(8), 733-744.

Konan, N. (2013). İlköğretim okulu yöneticilerinin okuma alışkanlıkları. Kuram ve Uygulamada Ĕ̈itim Yönetimi, 19(1), 31-59.

Kula, O. B. (2008). Kant estetiği ve yazın kuramı. İstanbul: Doruk Yayınları.

Kunt, A. (2007). Türkçe ve Almanca reklam metinlerinde ailenin konumu sözcükbilim anlambilim ve göstergebilim üzerine bir çalışma (Yayımlanmamış yüksek lisans tezi). Hacettepe Üniversitesi Sosyal Bilimler Enstitüsü, Ankara.

Lewandowsky, T. (1990). Linguistisches wörterbuch 1.2.3. Bande Heidelberg/Wiesbaden: QuelleMeyer.

MEB (2016). Uluslararası öğrenci değerlendirme programı PISA 2015 ulusal raporu. Ankara: MEB.

Odabaş, H., Odabaş, Z. Y. ve Polat, C. (2008). Üniversite öğrencilerinin okuma alışkanlığı: Ankara Üniversitesi örneği. Bilgi Dünyası Dergisi, 9(2), 431-465.

Portzig, W. (1995). Dil denen mucize. V. Ülkü (Çev.), Ankara: TDK.

Tanju, E. H. (2010). Çocuklarda kitap okuma alışkanlığına genel bir bakış. Aile ve Toplum Dergisi, 22(6), 30-39.

TDK, (2011). Güncel Türkçe sözlük. Ankara: TDK Yayınları.

Toklu, M. O. (2003). Dilbilime giriş. Ankara: Akçağ Yayınları.

Ulmann, S. (1978). Anlambilimi. A. Kocaman (Çev.), Türk Dili Dil ve Edebiyat Dergisi Dil Yazılarl Özel Saylsı, 34(38), 355-363.

Yılmaz, B. (1989). Okuryazarlık ve okuma alışkanlığı üzerine. Türk Kütüphaneciliği Dergisi. $3(1), 48-53$.

\section{Extended Abstract}

\section{Introduction}

The course titled "Understanding Techniques 1: Reading Education" is given in the 5th semester of Turkish language teaching programs. In this course, reading education sections of Turkish education sources are examined or, in these lessons, textbooks titled "reading education" are read. These books and chapters should reflect the field concept of reading, encourage reading. These books should prepare teacher candidates for reading instruction. Reading is a versatile concept. In other words, reading is an interdisciplinary concept. For this reason, it is difficult to determine the field concept of reading. However, Turkish teachers must have the field concept of reading.

The aim of this study is to determine the field concept of reading in theoretical books in the field of reading education. For this purpose, ten theoretical books were examined. When these books were determined, expert opinion was applied for the adequacy of representation. The concepts in the sampled books were classified and explained in the "findings" section. In addition, two sources addressing the development history of the German language and literature course were evaluated in order to determine the field concept of reading. Thus, differences in the field concept of reading in Turkish education and German language education are emphasized. In this study, the requirements related to reading education were determined. Suggestions for book authors were presented in this study.

\section{Field Concept}

Field concept holds an important place in linguistics and semantics. J. Trier, A. Jolles, K. Bühler, W. Portzig, L. Weisberger, B. Ipsen are the most important representatives of field concept theory. According to field concept theory, concepts are like mosaic. Every concept is related to other concepts. The meaning of a concept depends on its relation with the other concept. The field concept theory is closely related to language-thought and language-culture relationship. 


\section{Method}

This study is descriptive. Content analysis method was used in this study. In addition, linguistic concept analysis was conducted in this study. A semi-structured observation form was used when collecting data.

Theoretical books on reading education in Turkish education constitute the universe of this study. In the study, ten theoretical books were examined as samples. When the sample was selected, two faculty members working in Mersin University Education Faculty Turkish Education and Educational Sciences departments were consulted. In addition, two sources related to German language and literature were examined in the study. Detailed information about the books is available in the full text.

\section{Result and Discussion}

The results achieved in this study are as follows:

- Concepts found in Turkish books are: physiological concepts, physical concepts, habit, speed, text, knowledge, vocabulary, sociability and comprehension.

- Some concepts that are different from Turkish sources in German sources are: reading socialization, literary socialization, reception aesthetics, text and reader interaction, autonomy, individuality, reading as an identity / personality enhancing process, selfcritical reading, reading dynamics, reading climax, reading climate, reading motivation, reading experience, structring of reading.

- Nine concepts have been identified in ten books in Turkish. More than ten concepts have been identified in two German books. This shows that theoretical books in German are concept-based.

- There are more concrete concepts in Turkish sources and more abstract concepts in German sources. Abstract concepts encourage people to think. For this reason, German language sources are more authoritative than Turkish sources.

- Reading in Turkish sources is considered as a habit. But in German language sources reading is not considered as a habit, on the contrary reading is the destruction of habits. This is an important comparison to question the concept of reading habit.

- There isn't concept of "reception aesthetics" in Turkish sources. However, reception aesthetics in German language sources is one of the basic concepts for reading education.

- German sources intensively and effectively emphasize the relationship between reading, comprehension and thinking because this relationship is at the base of the reading.

- In German sources, concepts like "autonomy, self-realization, individuality, freedom" are encountered. Turkish sources have neglected these concepts.

- Reading socialization, literary socialization, literary self-socialization, literary communication can offer new possibilities for Turkish reading education researches.

The following suggestions can be made in this study:

- New concepts should be proposed in the field of Turkish reading education. In this context, research on concept proposals is needed.

- Foreign literature should be examined in the field of Turkish reading education.

- Theoretical resources in the field of reading education should be reconsidered.

- Comparisons can be made in different languages for reading education. 